\title{
NEW APPROACHES TO THE REVEGETATIONAND RECLAMATION OF OLD TAILING MANAGEMENT FACILITIES: THE EXAMPLE OF THE CASSANDRA MINES
}

\author{
Alifragkis D. ${ }^{1}$, Vavelidis M. ${ }^{2}$, Gazea B. ${ }^{3}$, Voulgaridou E. ${ }^{1}$, Galatsianou A. ${ }^{3}$ and \\ Daftsis E. ${ }^{3}$ \\ ${ }^{1}$ Aristotle University of Thessaloniki, Forestry and Natural Environment, Thessaloniki Greece, \\ dalifrag@for.auth.gr,v_elena7@hotmail.com \\ ${ }^{2}$ Aristotle University of Thessaloniki,vavelidi@geo.auth.gr \\ ${ }^{3}$ Hellas Gold SA, EmmyGazea@gr,eldoradogold.com, anastasia galatsianou@gr \\ eldoradogold.com
}

\begin{abstract}
Vegetation cover is a cost effective method for reclaiming old mine wastes and tailings disposal sites. Physicochemical characteristics of wastes and tailings are often inimical to successful vegetation establishment. In this research revegetation and reclamation of old tailings management facilities at Cassandra Mines was investigated. The research was conducted in three stages. In the first stage, the physicochemical characteristics of the mining wastes were studied and methods for reduction of the bioavailability of heavy metals by adding various amendments such as material rich in Mn and Fe oxides (by-products of pyrolusite industry, zeolite, phosphates, $\mathrm{Fe}$ oxides, $\mathrm{Fe} e^{o}$ etc.) were investigated. In the second stage, the suitability of different plant species for revegetation of the mine wastes in greenhouse conditions was investigated. The results of this stage showed that the species Nerium oleander can be used successfully to stabilize the surface of the old mining wastes followed by a reduction of heavy metals bioavailability. In the third stage (pilot experiment), the six best treatments of greenhouse experiment were used in two sites (Olympias, Karakoli) with three repetitions per treatment. The plants were fertilized and irrigated for two growth periods. Biometrical characteristics of Nerium oleander (leaf area, height of plants, weight of leaves and number of branches) and concentrations of the elements in the leaves of the plants were determined. One year after, a number of other plant species colonized the area with natural processes. These plants were recorded, collected and identified and the chemical compositions and bioaccumulation factors were determined. The growth of Nerium oleander was successful for almost all treatments. The revegetation and stabilization of the experimental plots resulted to a quick colonization by various plant species. Thirty five (35) different plant species were recorded in "old Olympias tailings pond" and forty (40) species in "old Karakoli tailings dam". Treatments affect the number of plant species colonized the experimental plots. The best treatments contained material rich in oxides of Fe and $\mathrm{Mn}$.
\end{abstract}

Keyswords: Mine wastes stabilization, revegetation of mine spoil, tails (TMF-tailing material facilities), phytoremediation. 


\section{Пєрі́⿱亠乂 $\psi \eta$}

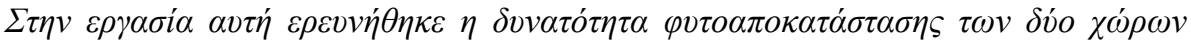

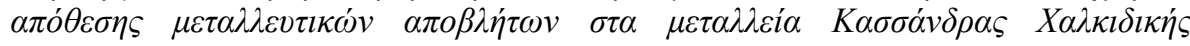

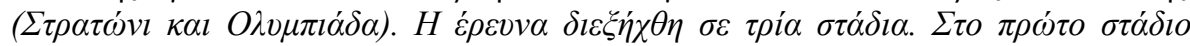

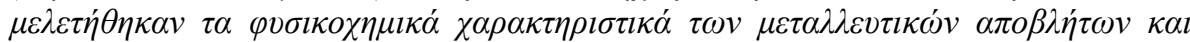

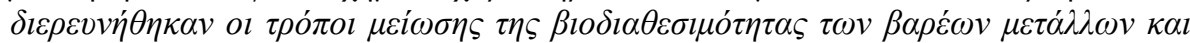

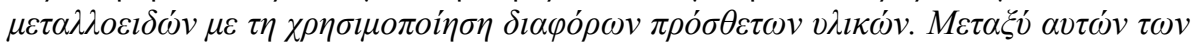

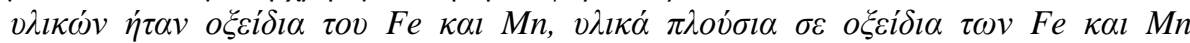

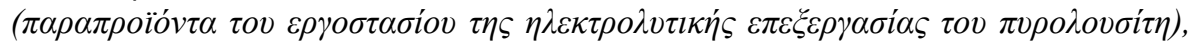

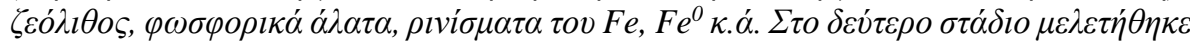

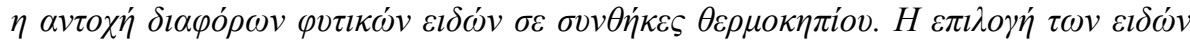

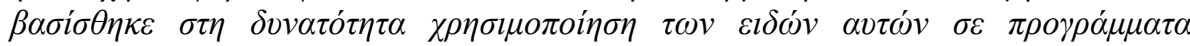

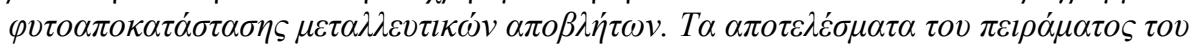

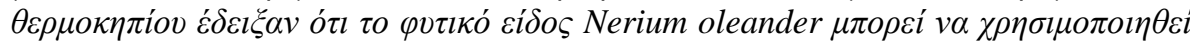

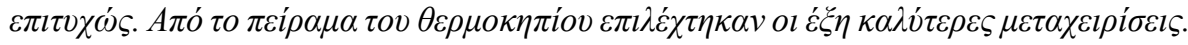

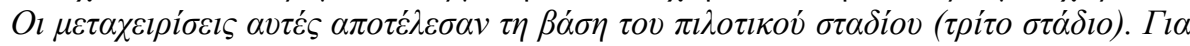
$\tau \eta v$ aร̌ı

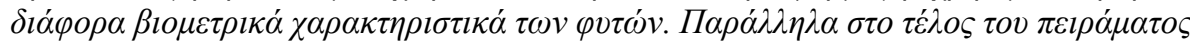

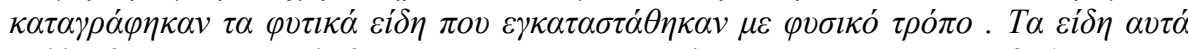

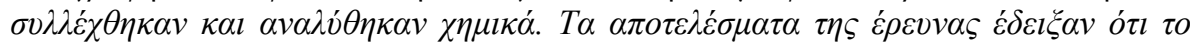

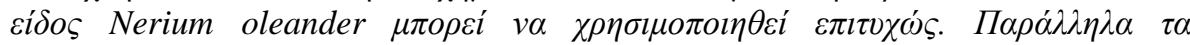

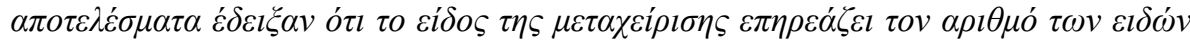

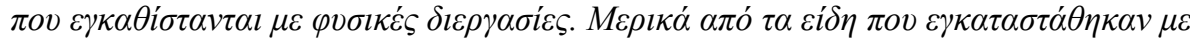

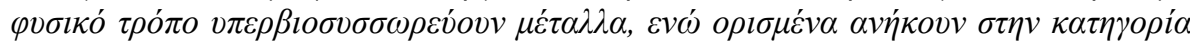

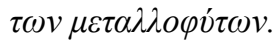

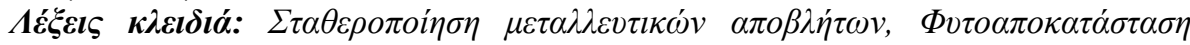

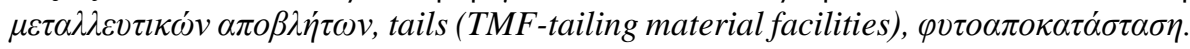

\section{Introduction}

In recent years, a strong interest in the development of new methods and technologies for extraction and exploitation of minerals combining both the economic and the environmental dimension has been expressed (Rumenjak et al., 2013; Van Zyl et al., 2013; Shtiza et al., 2013). It is now a requirement in most countries that reclamation schemes must be incorporated in mining proposals at the planning stage. At the same time, efforts are made to inform both citizens and stakeholders with scientific documentation and transparency of technologies that reduce environmental costs as well as how to deal with environmental problems, in order to accept the operation of mining activities (Craynon et al., 2013; Kolovos, 2013). Old mine wastes or poor mining materials had, on the economic circumstances of their times, no value. Today these are raw material for new treatment. This was made possible by using new and improved methods of enrichment. These practices of reprocessing and exploitation of mining waste, are expected to be used in the future. According to Lottermoser (2010), «waste of yesterday may be the mineral resources of the future".

Mine waste disposal sites such tails and dumps must be reclaimed before the end of mine exploitation activities. In its broadest sense, as reclamation of mining waste disposal areas means the attempt to create a steady state or restore the soil functions in a deprived area, to a new land use that has been preselected for the region and that is possible (European Commission, 2006). There is a growing need to reclaim such sites in order to increase environmental quality. Remediation of large areas by conventional techniques, which were used for small areas of heavily contaminated sites, is not feasible economically. These areas, potentially, provide alternative equivalents of degraded natural resources. In these cases, it is suggested to create suitable conditions to allow resettlement of a new ecological balance, thus reducing the risk to humans and the environment (European Commission, 2006). 
Some basic techniques and methods (physical, chemical and biological) have been employed to reclaim a tail or a mine waste disposal area. Chemical stabilization involves use of chemical stabilizers as amendments such $\mathrm{Fe}^{0}, \mathrm{Fe}_{2} \mathrm{O}_{3}, \mathrm{Fe}(\mathrm{OH})_{2}, \mathrm{CaCO}_{3}$, zeolite, $\mathrm{MnO}_{2}$, red mud from bauxite processing organic matter etc. (Ladeira et al., 2004; Chakravarty et al., 2002), This technique for mine wastes stabilization is temporary but it is useful tool prior to revegetation. The use of chelating agents has disadvantages because in some cases complexes are toxic and poorly photo-, chemo- and bio-degradable and can cause ground water pollution by uncontrolled metal dissolution and metal leaching. Several efforts have been made to reduce soluble forms of heavy metals (Kumpiene et al., 2006, 2008). The use of vegetation to stabilize mine wastes is a long term rehabilitation process. The unfavorable plant growth conditions that dominate in mine wastes sites have as a consequence these areas to be largely devoid of any natural vegetation, even many years after abandonment (Alifragkis et al., 2013). Because of the great variation in physical, chemical and biological properties between mine wastes, revegetation of such areas is limited and needs more focused researches. Successful revegetation can be a permanent and visually attractive solution and, at the same time, relatively inexpensive. A vegetation cover can be effective in providing the necessary surface stability by preventing wind erosion of contaminated particulates, and in reducing water pollution by interception of a substantial proportion of precipitation.

Several different methods for revegetation of mine wastes have been developed. For example direct seedling with native plant species or commercially available plants, planting small plants, seedling or planting with metal tolerant plants or metallophytes, etc. Some of them are attractive methods and have advantages and disadvantages. In all cases ameliorants and stabilization agents must be used.

Selection of plant species is one of the most critical factors in revegetation applied on contaminated areas. It is associated with the facts that (a) the waste materials differ from site to site, (b) the climatic conditions such as temperature and humidity differ from site to site, and (c) only a limited number of plant species are tolerant in high salt and metal concentrations. The aim of this research is the reclamation via revegetation of abandoned mine wastes of the Cassandra Mines.

\section{Material and Methods}

In the Chalkidiki peninsula, abandoned mine working sites are typical features of landscape. $\mathrm{Pb}, \mathrm{Zn}$, $\mathrm{Cu}$ occur principally in the form of sulfide minerals galena $(\mathrm{PbS})$, sphalerite $(\mathrm{Zn}, \mathrm{FeS})$, etc.

Northeastern Chalkidiki is the region of Greece with a great mining activity. Its mining history starts 2500 years ago since the time of Alexander the Great. Since the 90's the mines were abandoned, leaving behind several old disposal areas.

The experimental sites were located in Northern Greece, 1) at Olympias- mine, and 2) at Stratoni mine. The materials that make up mine wastes are various minerals such as arsenopyrite, pyrite galena, sphalerite etc. In Olympias, in a specifically designed area (tailing material facilities -TMF), mine wastes were deposited in liquid form (area approximately 30 hectares). Tailing are fine-grained deposits $(<2 \mathrm{~mm})$ from the final stage separators. After evaporation of the liquid phase the area covered with polyethylene sheets to reduce wind erosion temporarily. The variation of materials with depth is an important characteristic of the TMF. The texture of tailing materials is predominantly sandy loam. The chemical characteristics and bioavailability of nutrients are given in table 1. The Karakoli site, various mining waste (cake) in solid form were deposited (area approximately 3.5 hectares). Mine wastes came from the enrichment plant and sludge coming from the neutralization process. The chemical characteristics and bioavailability of nutrients are given in table 2 .

Experiment was carried out at three levels. The first level experiment refers to purely laboratory investigation on the properties of the mine wastes materials in order to reduce the amount of soluble forms of heavy metals by extraction experiments, columns with suction microlysimeter, etc. 
Table 1 - Mean chemical composition at Olympias site.

\begin{tabular}{|c|c|c|c|c|c|c|c|c|c|c|c|c|}
\hline \multirow[t]{2}{*}{$\mathrm{pH}$} & \multicolumn{2}{|c|}{$\begin{array}{c}\text { Water soluble } \\
(\mu \mathrm{g} / \mathrm{g})\end{array}$} & \multicolumn{4}{|c|}{$\begin{array}{c}\text { Leachable DTPA } \\
(\mu \mathrm{g} / \mathrm{g})\end{array}$} & \multicolumn{4}{|c|}{$\begin{array}{l}\text { Exchangeable } \\
(\mathrm{cmol} / \mathrm{Kg})\end{array}$} & \multirow[t]{2}{*}{$\mathrm{N}(\%)$} & \multirow{2}{*}{$\begin{array}{l}\mathrm{P}(\text { Olsen } \\
(\mu \mathrm{g} / \mathrm{g})\end{array}$} \\
\hline & \begin{tabular}{|l|l}
$\mathrm{Zn}$ & $\mathrm{C}$ \\
\end{tabular} & \begin{tabular}{l|l|l|}
$\mathrm{Cu}$ & $\mathrm{Fe}$
\end{tabular} & $\mathrm{Zn}$ & $\mathrm{Cu}$ & $\mathrm{Mn}$ & $\mathrm{Fe}$ & $\mathrm{Mg}$ & $\mathrm{K}$ & $\mathrm{Na}$ & $\mathrm{Ca}$ & & \\
\hline 7,15 & |0,34-- & \begin{tabular}{|l|l|}
1,12 & 23,5 \\
\end{tabular} & 8,2 & 2,98 & 2,52 & 140,9 & 0,34 & 40,07 & 0,81 & 7,50 & $<0,01$ & 15 \\
\hline
\end{tabular}

Table 2 - Mean chemical composition of Karakoli mine wastes.

\begin{tabular}{|c|c|c|c|c|c|c|c|}
\hline Location & \multirow[t]{2}{*}{$\mathrm{pH}$} & \multirow{2}{*}{$\begin{array}{c}\mathrm{P}(\text { Olsen }), \\
\mu \mathrm{g} / \mathrm{g}\end{array}$} & \multicolumn{5}{|c|}{ Exchangeable $(\mathrm{cmol} / \mathrm{kg})$} \\
\hline & & & $\mathrm{N}(\%)$ & $\mathrm{Ca}$ & $\mathrm{Mg}$ & K & $\mathrm{Na}$ \\
\hline 1 & 4,10 & 3,58 & 0,03 & 59,63 & 1,866 & 0,004 & 0,127 \\
\hline 2 & 2,81 & 3,55 & 0,044 & 34,56 & 0,899 & 0,012 & 0,510 \\
\hline 3 & 4,13 & 3,56 & 0,04 & 58,88 & 1,377 & 0,009 & 0,244 \\
\hline
\end{tabular}

\begin{tabular}{|c|c|c|c|c|c|c|c|c|c|}
\hline Location & \multicolumn{4}{|c|}{ Water soluble $(\mu \mathrm{g} / \mathrm{g})$} & \multicolumn{4}{|c|}{ Leachable DTPA $(\mu \mathrm{g} / \mathrm{g})$} & Water soluble $(\mu \mathrm{g} / \mathrm{g})$ \\
\hline & $\mathrm{Fe}$ & $\mathrm{Mn}$ & $\mathrm{Cu}$ & $\mathrm{Zn}$ & $\mathrm{Fe}$ & $\mathrm{Mn}$ & $\mathrm{Cu}$ & $\mathrm{Zn}$ & $\mathrm{Na}$ \\
\hline 1 & 15,00 & 91,80 & 0,14 & 2,52 & 3,06 & 6150 & 3,24 & 782 & 22,70 \\
\hline 2 & 28,70 & 68,60 & 0,72 & 7,15 & 237 & 6595 & 5,36 & 1650 & 14,60 \\
\hline 3 & 14,25 & 33,10 & 0,48 & 5,12 & 2,92 & 3648 & 3,84 & 24,30 & 24,30 \\
\hline
\end{tabular}

During this stage different amendments in varying proportions were used. More than 160 treatments were investigated and different materials, such as iron oxides, soil rich in iron oxides, manganese oxides material, rich in iron and manganese oxides like the by-product of the industry Tosoh-Hellas (as waste of the pyrolusite treatment), organic matter were tested. During this stage different plant species were selected which could potentially be used. The second level experiment refers to the greenhouse experiment, during which 36 treatments were initially used for each of the plant species chosen. The greenhouse experiment lasted two years, during which all necessary measurements of biometric characteristics of plants and the necessary chemical analyses have been done. This third level and most important experiment included pilot applications for the six best treatments (table 3 ). Each treatment comprised 36 plants with planting space 1x1 m. Each treatment was done in three replications (Voulgaridou, 2015).

The role of Fe and Mn oxides in the soil is significant not only because they are principal nutrient elements for the plants but also because they have the ability to stabilize heavy metals, to absorb anions such as As, Cr, P, cyanides, etc., to form chemical compounds, to oxidize various metals and to reduce the toxicity in the soil. The mechanism of chemical stabilization by $\mathrm{Mn}$ and Fe oxides as wastes of the pyrolusite industry Tosoh-Hellas has been described in the literature (Alifragkis et al. 2010, 2012a, 2012b, 2012c, 2013). The use of Fe oxides for reclamation of soil in polluted areas is referred, also, in the literature because they have the ability to absorb heavy metals and metalloids effectively (Mench et al., 2004, Hartley et al., 2004, Kumpiene et al., 2006, Lidelow et al. 2007). For example, absorption isotherms showed that the use of a low cost material $(50 \$ / \mathrm{t})$, rich in Fe and Mn oxides (8\% and 76,9\%, respectively) including, also, other oxides $\left(\mathrm{SiO}_{2}, \mathrm{~K}_{2} \mathrm{O}, \mathrm{Al}_{2} \mathrm{O}_{3}\right.$, etc.), removed significant quantities (up to $76 \%$ ) of $\mathrm{As}(\mathrm{V})$ and $\mathrm{As}(\mathrm{III})$ from polluted soil.

Biometric characteristics such, survival, plant height, number of lateral shoots, leaf area and leaves weight of the species Nerium oleander were measured. In addition the weight of roots and root surface, type of mycorrhiza and degree of root colonization by fungi were measured. More over colonization of each plot by plant species with natural processes in various treatments was studied. Samples of all above mentioned plant tissues were used for all necessary chemical analyses. 
Table 3 - Treatments and stratification of materials in the pilot experiment.

\begin{tabular}{|l|c|c|c|c|c|l|}
\hline Treatment/Substrate material & 1 & $2 *$ & 3 & $4 * *$ & 5 & 6 \\
\hline Mine wastes (\%) & 50 & 50 & 60 & 60 & 100 & - \\
\hline $\begin{array}{l}\text { Rich in Fe and Mn oxides materials as } \\
\text { wastes of pyrolusite industry (\%) }\end{array}$ & 20 & 20 & 10 & 10 & - & - \\
\hline Soil (\%) & 10 & 10 & 10 & 10 & - & 100 \\
\hline Rice husk (\%) & 10 & 10 & 10 & 10 & - & - \\
\hline Skeleton material (\%) & 10 & 10 & 10 & 10 & - & - \\
\hline
\end{tabular}

*Mixture was inserted as layer at the bottom, while the tailing material with a thickness of $40 \mathrm{~cm}$ at the top, ** Inoculation with Glomus intraradices fungus.

Stratification: Treatments 1,3 and 4

*Stratification: Treatment 2

Tailing material, thickness $\approx 40 \mathrm{~cm}$

Mixture of amendments (50\%) and tailing

material/mine wastes $(50 \%)$

Tailing disposal/mine waste area

Mixture of amendments (50\% or $40 \%)$ and tailing material $(50 \%$ or $60 \%)$.

**In treatment 4 , inoculation with the fungus Glomus intraradices

Tailing disposal/mine waste area

\subsection{Chemical analyses}

\subsubsection{Plant tissues}

Nitrogen was measured by the Kjeldahl method. The elements $\mathrm{Zn}, \mathrm{Cu}, \mathrm{Mn}, \mathrm{Fe}, \mathrm{K}$., $\mathrm{Na}$., $\mathrm{Mg}$, $\mathrm{Ca}$ and As were determined by the method of atomic absorption spectrophotometry after wet oxidation with a mixture of the $\mathrm{HNO}_{3}, \mathrm{H}_{2} \mathrm{SO}_{4}$ and $\mathrm{HClO}_{4}$ acids. $\mathrm{P}$ was measured by using a spectrophotometer.

\subsubsection{Mine wastes materials}

Nitrogen was determined by the method of Kjeldahl. The water-soluble elements and the extractable cations of $\mathrm{Mn}, \mathrm{Cu}, \mathrm{Zn}, \mathrm{Fe}$ by the DTPA (Diethylenetriaminepentaceticacid) method, while the exchangeable cations $\mathrm{K}, \mathrm{Ca}, \mathrm{Mg}$ and $\mathrm{Na}$ by the method of atomic absorption spectrophotometry. The chemical composition of tail material was determined by ICP-MS (Inductively coupled plasmamass spectrometry).

\section{Results and discussion}

\subsection{Greenhouse experiment}

Results showed that the treatment affects the biometric and the chemical characteristics of the plants. For example, results showed that treatments affect the length of the root system. The greatest root length was observed in treatments containing skeletal material (gneiss) in proportion of 30\% 
combined with rice husks, rich in $\mathrm{Fe}$ and $\mathrm{Mn}$ oxides material (wastes of the pyrolusite industry Tosoh-Hellas), and/or soil and mine wastes material (Fig. 1).
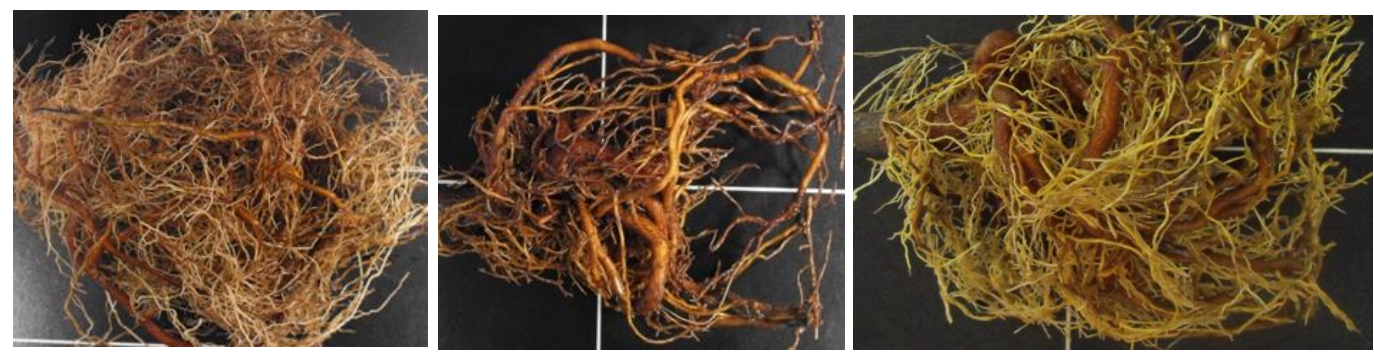

Figure 1 - Growth and development of plant root systems in the greenhouse experiment.

From the analytical data, it appears that all treatments containing by-products rich in Fe and $\mathrm{Mn}$ oxides in combination with mycorrhizal fungi cause greater root growth.

Regarding root biomass, the results showed that the biomass of the root system decreased slightly in all treatments. Regarding the frequency of mycorrhiza colonization, the results showed that all treatments with tailing material significantly increased the frequency of colonization by the fungus Glomus intraradices. The intensity of mycorrhiza colonization appears to increase in treatments containing rich in $\mathrm{Fe}$ and $\mathrm{Mn}$ oxide materials (by-product from the Tosoh-Hellas industry as waste of the pyrolusite treatment).

One of the very important result of the greenhouse experiment was that in all treatments containing rich in Fe and $\mathrm{Mn}$ oxides material, $\mathrm{Zn}$ accumulation in roots, even compared with that of the check treatment, decreases from $3.13 \mathrm{mg} /$ plant to $1.45 \mathrm{mg} / \mathrm{plant}$, while accumulation of Mn increased from 11.92 to $14.29 \mathrm{mg} / \mathrm{plant}$. The same result like Mn was observed for the accumulation of $\mathrm{Cu}$. Mycorrhiza increased the accumulation of Fe from 38.52 to $100.02 \mathrm{mg} / \mathrm{plant}$.

Between treatments, the best results were found in treatments with stratification of materials, i.e. by placing the rich in $\mathrm{Fe}$ and $\mathrm{Mn}$ oxides material mixed with the other materials on the bottom of the pots (as background) and the filling with tailings material. Thus, taking into account many of the data of the greenhouse experiment, a combination of treatments applied in the pilot experiment.

\subsection{Main results from the pilot experiment.}

Survival of Nerium oleander plants in the end of second growing season was 100\% in Olympias site in contrast to Karakoli site in which the survival was less (table 4).

Table 4 - Mean survival of Nerium oleander (\%).

\begin{tabular}{|c|c|c|}
\hline Treatment & Olympias & Karakoli \\
\hline 1 & 100 & 82 \\
\hline 2 & 100 & 92 \\
\hline 3 & 100 & 86 \\
\hline 4 & 100 & 94 \\
\hline 5 & 100 & 0 \\
\hline 6 & 100 & 95 \\
\hline
\end{tabular}

\subsubsection{Height}

In Olympias site (TMF), the data showed that the mean height of the Nerium oleander plants was between $38.95 \mathrm{~cm}$ (treatment 3) and $80.36 \mathrm{~cm}$ (treatment 2) after the first growing season and between 80.07 (treatment 5) and 140.50 (treatment 2) after the second growing season (Fig. 2). 
In Karakoli site data shows that, for the first growing season the mean height of Nerium oleander was between $35.92 \mathrm{~cm}$ (treatment 4) and $43.40 \mathrm{~cm}$ (treatment 6). For the second growth period mean height of plants for was between $50.80 \mathrm{~cm}$ (treatment 4) and $96.10 \mathrm{~cm}$ (treatment 1) (Fig. 3).

As in the greenhouse experiment, a good growth of plants roots (increase of their weight and length) was observed (Alifragkis et al., 2013, Fig. 4).

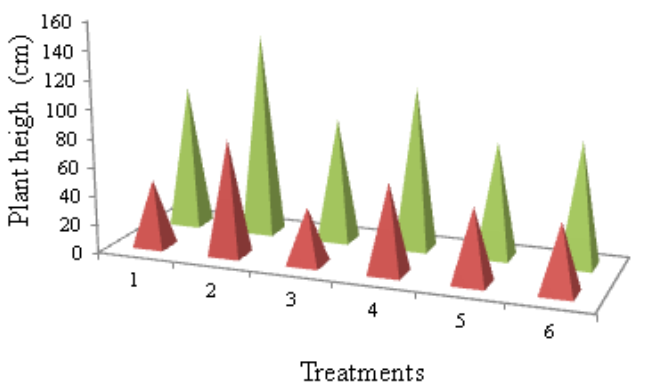

Figure 2 - Growth of Nerium oleander plants at "Olympias" site.

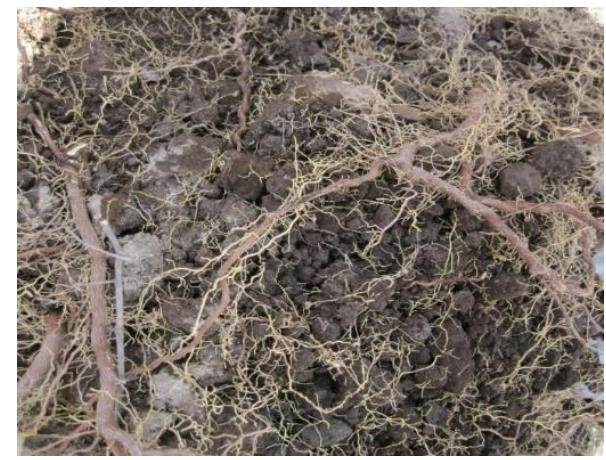

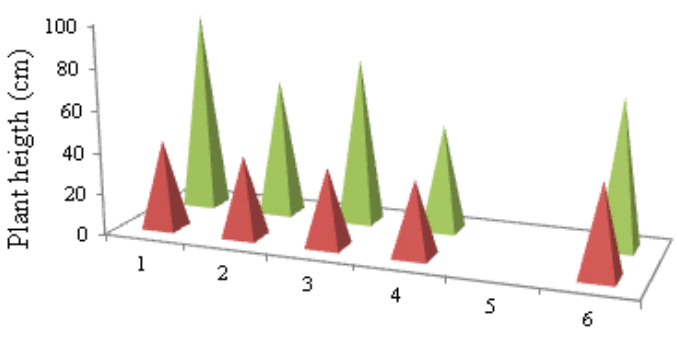

Treatments

Figure 3 - Growth of Nerium oleander plants at "Karakoli" site.

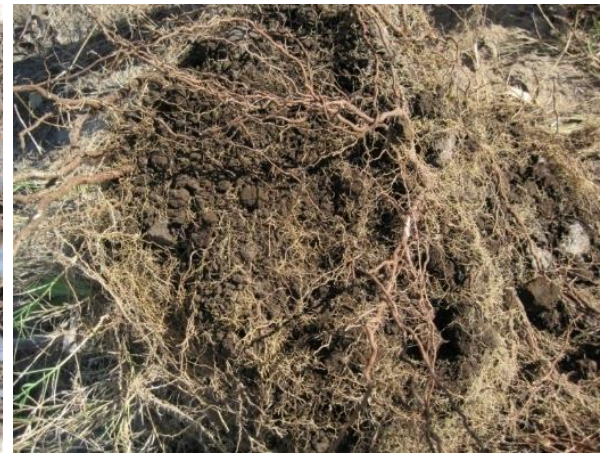

Figure 4 - Growth and development of plant root systems at Olympias site in the pilot experiment.

\subsubsection{Leaf area}

Data from Olympias site showed that the mean leaf area of Nerium oleander was between $19.61 \mathrm{~cm}^{2}$ (treatment 3) and $33.16 \mathrm{~cm}^{2} /$ leaf (treatment 2). Statistically significant differences (criterion Bonferroni) were observed between treatments 1 and 2, 1 and 4, 2 with all other treatments, 3 and 4, 4 with all other treatments, 5 and 2, 5 and 4, 6 and 2, and 6. For Karakoli site, the data showed that the mean leaf area of Nerium oleander was between $15.94 \mathrm{~cm}^{2} /$ leaf (treatment 2) and 22.09 $\mathrm{cm}$ /leaf (treatment4). Differences in leaf area were relatively small between the two sites (Fig. 5).

The best treatments referred on leaf area for Karakoli site were the treatments 1 and 4, while for Olympias site were the treatments 2 and 4. These treatments contained rich in Fe oxides and Mn material from industrial byproducts, while treatment 4 was moreover inoculated with the fungus Glomus intraradices (mycorrhiza symbiosis).

\subsubsection{Branching}

For Olympias site (TMF), the data showed that the mean number of branches of Nerium oleander ranged between 2.75 (treatment 3 ) and 6.67 (treatment 2). Statistically significant differences, for significance level of 95\%, were observed between treatments 1 and 2,1 and 4, 2 and 3,2 and 5, 2 and 6, 3 and 4, 4 and 5, and between 4 and 6. 
(a)

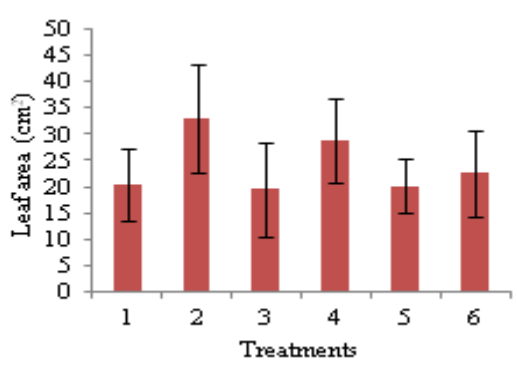

(b)

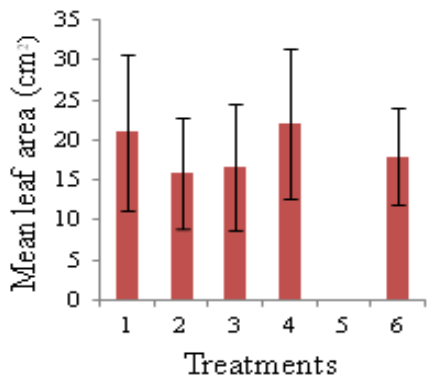

Figure 5 - Leaf area in different treatments (a. Olympias, b. Karakoli).

For Karakoli site, the mean number of branches of the Nerium oleander plant ranged between 2.75 (treatment 1) and 4.35 (treatment 4). Statistically significant differences, for significance level of 95\%, were observed between treatments 1 and 2, 1 and 4, 1, and 6, 3 and 4, and 6 and 1 (fig. 6).

\subsubsection{Leaves weight}

The mean weight of Nerium oleander leaves to different treatments range between 10.46 and $15.57 \mathrm{~g} / 100$ leaves in Olympias site and between 6.1 and $10.13 \mathrm{~g} / 100$ leaves in Karakoli site. Statistically significant differences between treatments were not found within each site. Between the two mine waste disposal sites the largest differences in leaves weight were observed in treatments 1,4 and 6 (Fig. 7).

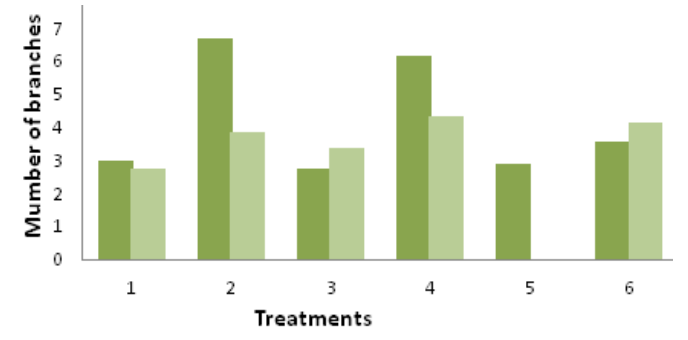

Figure 6 - Number of branches*

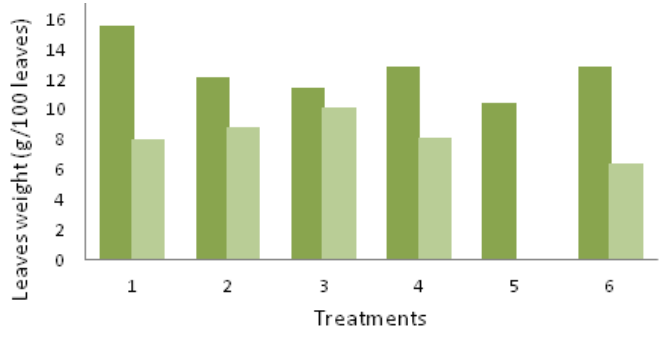

Figure 7 - Leaves weight*

$\left(* 1^{\text {st }}\right.$ column: Olympias site, $2^{\text {nd }}$ column: Karakoli site).

\subsubsection{Site colonization by plants}

One of the key results of the present research was that from the first year of experiment different plant species colonized the area through natural processes (fig. 8). The total number of species that were recorded in Olympias tail was 35, namely Polygonum aviculare, Tragus racemosus, Digitaria sanguinalis, Vebrasscum cylindrocarpum, Oxalis corniculata, Persicaria sp., Chenopodium album, Centaurea diffusa, Cynodon dactylon, Sorbum halepense, Cichorium intybus, Euphorbia cyparisias, Echinochloa column, Calystegia silvatica, Solanum nigrum, Cyperus longus, Solanum elaeagnifolium, Melilotus sp., Conyza bonariensis, Chenopodium botrys, Ailanthus altissima, Aster trifolium, Rumex pulcher, Cleone omithopodoides, Phytolacca americana, Rumex acetosa, Portulacca oleracea, Sanguisorba minor, Balota nigra, Dactylis glomerata, Piptatherum miliaceum, Rubus ulmifolius, Carduus acicularis, Xanthium spinosum.

Forty (40) plant species were recorded in Karakoli mine waste deposit area (Fig. 8), namely Persicaria sp., Cyperous longus, Amaranthus albus, Echinocloa column, Polygonum aviculare, Setaria viridis, Cynodon dactylon, Chenopodium album, Sorghum halepense, Euphorbia maculate, Solanum nigrum, Carthamus lanatus, Anagallis arvensis, Chenopodium sp., Cruciferae, Rosa sempervirens, Rubus ulmifolius, Rumex pulcher ssp.woodsii, Lolium perenne, Xanthium spinosum, Digitaria sanguinalis, Ranunculus muricatus, Arenaria leptoclados, Myosotis ramosissima, 
Portulaca oleracea, Campanula sparsa, Ruscus aculeatus, Chenopodium vulgare, Filago vulgaris, Boraginaceae, Verbascum undulatum, Apera spica-venti, Achillea sp., Sanguisorba minor, Rumex pulcher, Galium aparine, Hypericum perforatum, Pteridium aquilinum, Xanthium strumarium, Verbena officinalis.
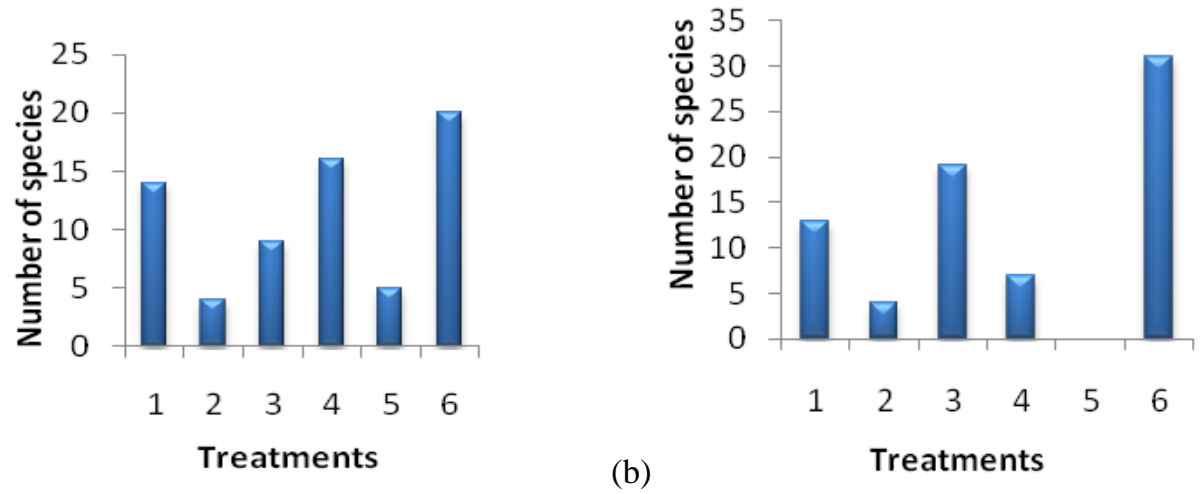

Figure 8 - Number of species colonized the experimental plots (a. Olympias, b. Karakoli).

After surface stabilization of mine wastes sites, they were colonized by different plant species with natural processes. The literature states that the greater the number of plant species installed in an area, the greater stability of plant communities occurred (Tilman et al., 1996, 1997; Hector et al., 2000). It is worthy to mention that no any plant species was installed with natural processes in Cassandra mine waste disposal sites during the last 35 years.

The type of treatment affected the number of species which may be used for phytoremediation effectively. Some of the plant species colonized the experimental sites behave as metal bioaccumulators. A typical case is Vebrascum undulanum in Olympias site, where Mn concentration in its tissues was $13,854 \mu \mathrm{g} / \mathrm{g}$ without showing any symptom of toxicity.

One of the criterions that characterized various plants as bioaccumulators is the bioaccumulation factor (Sarma, 2011). Analytical data indicated that in most cases, and in two experimental sites ("Olympias" and "Karakoli '), the bioaccumulation factor of heavy metal in most plants species was $>1$, a minimum value to characterize a plant species as metal bioaccumulator. In "Olympias" site, the Bioconcentration factor $(\mathrm{BCF})$ of $\mathrm{Cu}$ ranged between 0.13 and 25.51 and for "Karakoli" site between 0.88 and 60.48 for different species and different treatments. For $\mathrm{Zn}$, these values ranged between 2.50 and 29.07 ("Olympias" site) and between 1.13 and 52.30 ("Karakoli" site), and for Mn between 36.56 and 9,043.51 ("Olympias" site) and between 1.02 and 9,413.36 ("Karakoli" site). Between the two sites BCF was higher in Karakoli.

It should be noted that with the time and under continuous improvement of conditions, the composition of natural vegetation varies. It is also significant that, two years after the chemical stabilization and phytoremediation, mosses appeared to grow in some treatments (Fig. 9).

\subsubsection{Plant evaluation as metal bioaccumulators}

Plant evaluation as metal bioaccumulators based on the use of various indicators such as Bioconcentration factor. Bioconcentration factor $(\mathrm{BCF})$ defined as the ratio between metal concentration in above ground biomass and metal concentration in soil. Greater bioaccumulation factor means that this species can be considered suitable to be used in phytoremediation programs (Ma et al., 2001). 

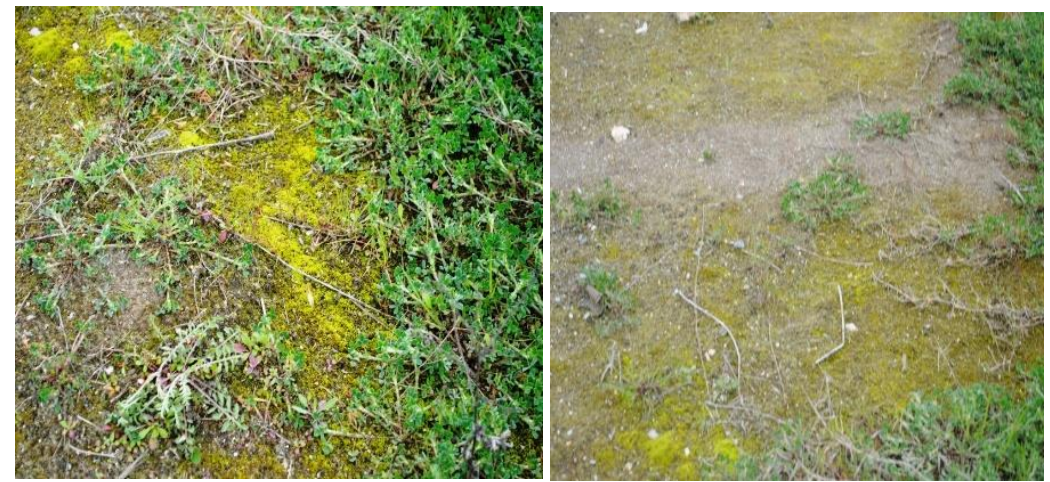

Figure 9 - Appearance of mosses in some treatments two years after the chemical stabilization and phytoremediation showing the improvement of growth conditions of tailing materials at Karakoli site.

$\mathrm{BCF}$ varies with the plant species, metal, treatment and the type of mine wastes. For Cu this factor ranged between 0.13 and 25.51 for Olympias site and between 0.88 and 60.48 for "Karakoli" site. For $\mathrm{Zn}, \mathrm{BCF}$ ranged between 2.50 and 29.07 and between 1.13 and 52.30 respectively. For Mn BCF ranged between 36.56 and 9,043 and between 1.02 and 9,413, respectively. Between two types of metal wastes Karakoli have maximum values of BCF. Between plant species BCF varied widely. For example BCF for $\mathrm{Cu}$ was low in Ailanthus altissima (0.51) and high in Solanum nigrum (24.55) for Olympias waste deposits. Bioconcentration factor for $\mathrm{Zn}$ was always $>1$ in all treatments. For Olympias site, the BCF of Zn was higher (18.58) in Cichorium intybus and for "Karakoli" deposit area, the BCF was 52.30 in the species of Echinocloa column. BCF for Mn was highest for the species of Rumex pulcher $(9,043)$ in "Olympias" site and in "Karakoli" for the species of Solanum nigrum $(9,413)$. This means that many species of them colonized the mine wastes can be used for phytoremediation programs in contaminated areas by heavy metals.

\subsubsection{Problems occurred during the pilot experiments in Karakoli disposal area}

Two main problems emerged during the first year of the pilot experiment. One of them was increased concentration of various soluble salts (mainly sulphate) on the surface of the mine wastes (Fig. 10) and the other one was the formation hardpan and cemented horizons during the summer time, that did not allow root growth. Both are related to the texture and the mineralogical composition of the wastes.
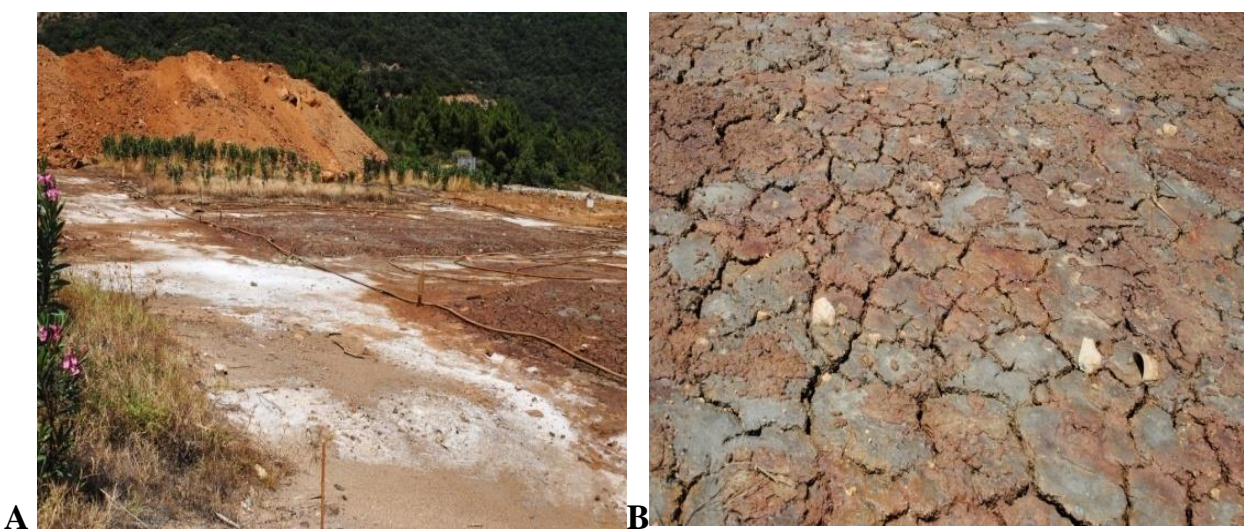

Figure 10 - A: Soluble salts concentrated on the surface of the mine wastes due to upward capillary movement of salt solution and evaporation, B: Cracks due to concentration of Na ions in the soil surface and water evaporation during the summer time. 
These two problems were treated by adding limestone skeletal material in proportion of $10-15 \% \mathrm{v} / \mathrm{v}$ up to a depth of $40 \mathrm{~cm}$, as shown in Figure 11, illustrating the additional experiments. Note that after the additional treatments, plant survival was $94 \%$ and the experimental plots were colonized by different plant species.
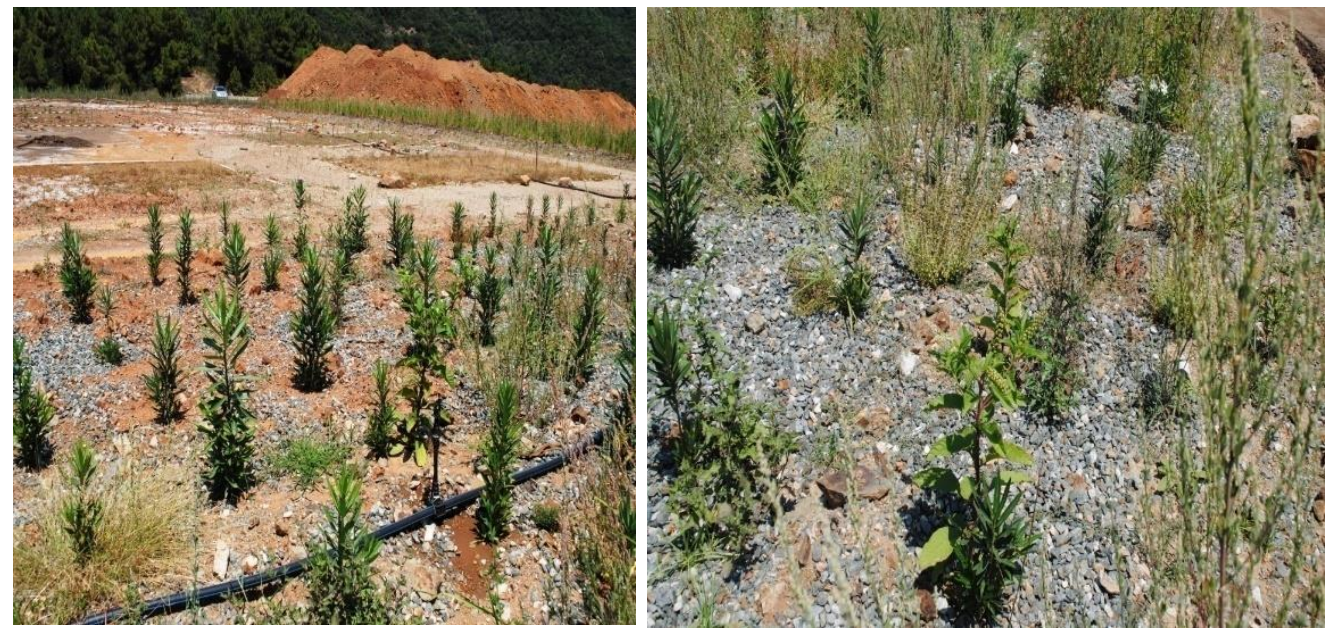

Figure 11 - Improvement of soil conditions by mixing limestone skeletal material with mine wastes for plants to grow in Karakoli site.

\section{Conclusions}

Phytoremediation of mine wastes in both sites is possible after chemical stabilization of wastes.

For chemical stabilization of mine wastes, by-products from of a pyrolusite industry, rich in iron and manganese oxides could be used with very good results. The use of these wastes as amendments had very good results improving the growth of plants.

The skeletal material such limestone gravel improved the growing conditions while rise husk improved the biological activity of mine wastes.

Mycorrhizal fungi improved growth of Nerium oleander under toxic conditions. The appearance of mosses in some treatments, two years after the chemical stabilization and phytoremediation, indicates the improvement of mine wastes conditions.

Reclamation of contaminated areas using phytoremediation processes includes several steps and materials such as study of mine wastes characteristics, use of amendments, increase of plant tolerance to high metal concentrations, etc., but it needs continuous monitoring of plants during the first period.

The type of treatment affects the biometric characteristics of the Nerium oleander, colonization of mine waste by plants and metal bioaccumulation factor.

Hardpan and cemented horizons can be avoided by adding skeletal material (rock fragments) that

Nerium oleander stabilizes metals and metalloids in root system and reduces phytotoxicity, while $\mathrm{Fe}$ and $\mathrm{Mn}$ oxides create complex substances, thus, limiting the adsorption and affecting the phytotoxicity. Analytical data of this research indicate that all treatments containing material rich in $\mathrm{Fe}$ oxides and $\mathrm{Mn}$ or $\mathrm{Fe}^{0}$ affect heavy metals and metalloids concentration of root, stem and leaves of Nerium oleander while plants show richer root system. 


\section{Acknowledgements}

The authors thank Hellas-Gold Company and the staff of Health-Safety and Environment Department for their support in performing this research.

\section{References}

Alifragkis, D., Gazea, E., Pavlidou, A., Papaioannou, A., Barbagiannis, N., Apostolidis, S. and Strouthopoulos, G., 2010. Reducing bioavailability of arsenic in ore enrichment materials with electrolytic pyrolusite process by-products, Proceedings of $13^{\text {th }}$ Congress of Hellenic Soil Science Society, Thessaloniki 2012 Larissa, (in Greek), 161-175.

Alifragkis, D., Voulgaridou, E., Orfanoudakis, M., Daftzis, E., Charaklias, I., Papaioannou, A., Vavelidis, M., Alifragkis, E., Voulgaropoulou, M. and Galatsianou, A., 2012a. Phytoremediation of residual deposits of Kassandra mines after chemical stabilization by using materials rich in Fe and Mn oxides, Proceedings of $14^{\text {th }}$ Congress of Hellenic Soil Science Society, Thessaloniki (In Greek).

Alifragkis, D., Voulgaridou, E., Pavlidou, A., Papaioannou, A. and Orfanoudakis, M., 2012b. The use of pyrolusite electrolytic process by-product for reclamation of limestone quarries, Proceedings of $14^{\text {th }}$ Congress of Hellenic Soil Science Society, Thessaloniki (In Greek).

Alifragkis, D., Voulgaridou, E., Daftsis, E. and Characlias, I., 2012c. Reclamation of old tailing disposal area of Olympias, Halkidiki Mine, $3^{\text {rd }}$ International Conference on Industrial and Hazardous Waste Management, Chania, Crete, Greece, 12-14 Sept. 2012.

Alifragkis, D., Vavelidis, M., Orfanoudakis, M., Galatsianou, A., Voulgaridou, E., Voulgaropoulou, M. and Alifragki, M., 2013. Installation of natural vegetation on old tailing disposal area at Olympias Halkidiki mine, after chemical stabilization and phytoremediation, $6^{\text {th }}$ International Conference on Sustainable Development in the Minerals Industry, 30 June - 3 July 2013, Milos island, Greece, 435-445.

Chakravarty, S., Dureja, V., Bhattacharyya, G., Maity, S. and Bhattacharjee, S., 2002. Removal of arsenic from groundwater using low cost ferruginous manganese ore, Water Research., 36, 625-632.

Craynon, J.R., Sarver, E.A. and Karmis, M.E., 2013. The role of science in public ecology and sustainable development in mining, 6th International Conference on Sustainable Development in the Minerals Industry, 30 June - 3 July 2013, Milos island, Greece, 77-82.

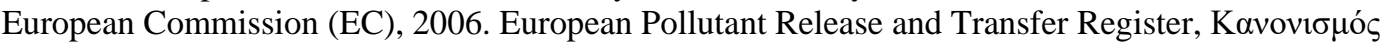
(EC Regulation 166/2006/EK).

Hartley, W., Edwards, R. and Lepp, N.W., 2004. Arsenic and heavy metal mobility in iron oxideamended contaminated soils as evaluated by short-and long term leaching tests, Environ. Pollution., 131, 495-504.

Hector, A., Dobson, K., Minns, A., Bazeley-White, E. and Lawton, J. H., 2001. Community diversity and invasion resistance: An experimental test in a grassland ecosystem and a review of comparable studies, Ecol. Res., 16, 819-831.

Kolovos, C.J., 2013. Corporate social responsibility and the future of mining in Greece, $6^{\text {th }}$ International Conference on Sustainable Development in the Minerals Industry, 30 June-3 July 2013, Milos island, Greece, 160-166.

Kumpiene, J., Ore, S., Renella, G., Menech, M., Lagerkvist, A. and Maurice, C., 2006. Assessment of zerovalent iron for stabilization of chromium, copper, and arsenic in soil, Environ. Pollut., 144, 62-69.

Kumpiene, J., Lagerkvist, A. and Maurice, C.M., 2008. Stabilization of As, Cr, Cu, Pb, and $\mathrm{Zn}$ on soil using amendments- A review, Waste Management, 28, 215-225.

Ladeira, A.C. and Cimineli, V.S.T., 2004. Adsorption and desorption of arsenic on an oxisols and its constituents, Water Res., 36, 2087-2094. 
Lidelow, S., Ragnvaldsson, D., Leffler, P., Tesfalidet, S. and Maurice, C., 2007. Field trials to assess the use of iron-bearing industrial by-products for stabilisation of chromated copper arsenatecontaminated soil, Science of the Total Environment, 387, 68-78.

Lottermoser, B.G., 2010. Mine Wastes Characterization, Treatment, Environmental Impacts ( $3^{\text {nd }}$ edition), Springer-Verlag, Berlin/London/NY.

Ma, L.Q., Komar, K.M., Tu, C., Zhang, W., Cai, Y. and Kenelly, E.D., 2001. A fern that hyper accumulates arsenic, Nature, 409, 579-582.

Marschner, H., 1995. Mineral nutrition of higher plants ( $2^{\text {nd }}$ edition), Academic press, London/NY.

Mench, M., Bussiere, S., Boisson, J., Castaing, E., Vangronsveld, J. and Ruttens, A., 2002. Progress in remediation and revegetation of the barren Jales gold mine spoil after in situ treatments, Plant Soil, 249, 187-202.

Rumenjak, D., Rajković, D. and Štambuk, S., 2013. Some principles of expert systems for environment and mining, $6^{\text {th }}$ International Conference on Sustainable Development in the Minerals Industry, 30 June - 3 July 2013, Milos island, Greece, 44-47.

Sarma, H., 2011. Metal hyperaccumulation in plants: a review focusing on phytoremediation technology, J. Environ. Sci. Technol., 4(2), 118-138.

Shtiza, A., Doome, R. and Wyart, M., 2013. Reducing the environmental footprint in the industrial mineral sector: Case studies and industry innovation initiatives, $6^{\text {th }}$ International Conference on Sustainable Development in the Minerals Industry, 30 June-3 July 2013, Milos island, Greece, 527-531

Tilman, D., Wedin, D. and Knops, J., 1996. Productivity and sustainability influenced by biodiversity in grass-land ecosystems, Nature, 379, 718-720.

Tilman, D., Knops, J., Wedin, D., Reich, P., Ritchie, M. and Siemann, E., 1997. The influence of functional diversity and composition on ecosystem processes, Science, 277, 1300-1302.

Van Zyl, D., Chanda, M. and Brune, J., 2013. WFEO Task Force: Environmentally sound engineering technologies and practices in mining, 6th International Conference on Sustainable Development in the Minerals Industry, 30 June-3 July 2013, Milos island, Greece, 380-385.

Voulgaridou, E., 2015. Reclamation of soil in polluted areas, PhD Thesis, School of Forestry and Natural Environment, Aristotle University of Thessaloniki, Greece (In Greek), 266 pp. 